\title{
Asymmetric Bio- and Chemoreduction of 2-Benzylidenecyclopentanone Derivatives
}

\author{
Bogdan Štefane, Uroš Grošelj, Jurij Svete and Franc Požgan \\ Faculty of Chemistry and Chemical Technology, University of Ljubljana, Večna pot 113, SI- 1000 Ljubljana, Slovenia \\ ${ }^{*}$ Corresponding author: E-mail: franc.pozgan@fkkt.uni-lj.si
}

Received: 16-05-2017

Dedicated to Professor Emeritus Miha Tišler, University of Ljubljana, on the occasion of his $90^{\text {th }}$ birthday.

\begin{abstract}
Highly efficient asymmetric reduction of 2-benzylidenecyclopentanone derivatives to give the respective exocyclic allylic alcohols in $e e^{\prime}$ s up to $96 \%$ was performed with chiral oxazaborolidine-based catalysts. Complete enantioselectivity furnishing $(S)$-configured alcohol product could be achieved by bioreduction of 2-(4-chlorobenzylidene)cyclopentanone with Daucus carota root. The synthesized compounds may be used as enantiomerically enriched standards for the monitoring of the enzyme-catalyzed redox processes.
\end{abstract}

Keywords: Enantioselective reduction, cyclopentanone, AKR1C inhibitors, oxazaborolidine, bioreduction

\section{Introduction}

Chiral alcohols are important building blocks and intermediates in the synthesis of pharmaceuticals, fine chemicals, agrochemicals, flavors and fragrances, as well as functional materials. ${ }^{1}$ Since ketones represent one of the most common families of unsaturated compounds, their asymmetric reduction represents the simplest and most powerful method for the preparation of enantiomerically enriched alcohols. The stereospecific reduction of carbon$\mathrm{yl}$ groups to the corresponding alcohols is also a functionalization reaction involved in the metabolism of endogeneous compounds and xenobiotics containing these groups. Thus, it is often catalyzed by enzymes belonging to either dehydrogenase/reductase superfamily or the aldo-keto reductase (AKR) superfamily. ${ }^{2}$ The human members of the AKR subfamily $1 \mathrm{C}$ are involved in the biosynthesis and inactivation of steroid hormones, and also in the biosynthesis of neurosteroids and prostaglandins. ${ }^{3}$ These enzymes reduce carbonyl containing substrates to alcohols and also function in vivo as ketosteroid reductases, and thus regulate the activity of androgens, estrogens and progesterone in target tissues, and ligand occupancy and transactivation of their corresponding receptors. ${ }^{4}$ Aberrant expression and action of AKR1C enzymes may lead to an imbalance in the metabolism of steroid hormones, and to further development of different patho- physiological conditions. ${ }^{5}$ These enzymes thus represent promising therapeutic targets in the development of new drugs. In the literature, structurally different compounds have been evaluated as AKR1C inhibitors, for example dietary phytoestrogens, ${ }^{6}$ benzodiazepines, ${ }^{7}$ cinnamic acids, ${ }^{8}$ benzofurans, and phenolphthalein derivatives, ${ }^{9} \mathrm{Ru}(\mathrm{II})$ complexes ${ }^{10}$ salicylic and aminobenzoic acids derivatives, as well as some nonsteroidal anti-inflammatory drugs and their analogues. ${ }^{11,12}$ In spite of a plethora of potent inhibitors of steroid metabolizing enyzmes that have emerged, the search for new and more selective ones is an important field of investigation. Štefane et al. ${ }^{13}$ indentified compounds based on cyclopentane scaffold, which are AKR1C1 and AKR1C3 substrates active in the low micromolar range, and thus represent promising starting points in the development of potential agents for treatment of hormone-dependent forms of cancer and other diseases involving these enzymes. AKR1C inhibitors are not only interesting as potential agents for the treatment of diseases, but also as molecular tools in the study of the pathophysiological roles of these enzymes. In the recent study Beranič et al. introduced new enzymatic assays employing racemic 2-(4-chlorobenzylidene)cyclopentanol (CBCP-ol) and its ketone counterpart 2-(4-chlorobenzylidene)cyclopentanone that allow monitoring of AKR1C-catalyzed reactions in the reductive and oxidative directions. ${ }^{14}$ Since enzymes perform highly stereoselective reactions, it seems 
useful to know, which enantiomer of CBCP-ol is involved in the redox process. For this reason we present herein the synthesis of enantiomerically enriched cyclopentyl alcohols (CBCP-ol and its 4-methoxy analogue) via the asymmetric chemo- and bioreduction of substituted 2-benzylidenecyclopentanones, which can serve as standards in monitoring of AKR1C-catalyzed reactions. The reduction of the benzene-fused analogue, indanone-derived chalcone, to the corresponding secondary allylic alcohol is also included.

\section{Results and Discussion}

The starting compounds, $\alpha$-arylmethylene cyclic ketones 3 and $\mathbf{6}$ were synthesized in a base-induced aldol condensation from cyclopentanone (1) or 1-indanone (5) and the corresponding $p$-substituted benzaldehydes 2 following slightly modified literature procedure ${ }^{15}$ (Scheme 1). The reaction of cyclopentanone with $p$-methoxybenzaldehyde (2b) towards benzylidenecyclopentanone $\mathbf{3 b}$ proceeded smothly, while using $p$-chlorobenzaldehyde (2a), besides the desired product 3a, symmetrical abis(benzylidene) derivative $\mathbf{4 a}$ was isolated as the by-product. 1-Indanone reacted with $p$-chlorobenzaldehyde leading to the product 6 in a very low $9 \%$ isolated yield. We were not, however, interested in the optimization of these aldol condensation reactions.

With $\alpha, \beta$-unsaturated ketones $\mathbf{3}$ and $\mathbf{6}$ in hand, we investigated different methods for the selective carbonyl reduction to obtain the highest possible enantiomeric excess of the corresponding allylic alcohol products with exocyclic $\mathrm{C}=\mathrm{C}$ double bond.

The most elegant method for the asymmetric reduction of prochiral ketones is either homogeneous or heterogeneous hydrogenation or transfer hydrogenation catalyzed by chiral metal catalysts. ${ }^{16}$ Highly efficient asymmetric hydrogenation of $\alpha$-arylmethylene cyclopentanones was realized by chiral tailor-made iridium-spiroaminophosphine catalysts $;{ }^{17}$ for example, reduction of $\mathbf{3 b}$ gave $\mathbf{7 b}$ with $95 \%$ ee (enantiomeric excess). Unfortunately, in our case the use of some commercially available chiral rhodium and ruthenium catalysts $\mathbf{C 1 - C 4}$ (Figure 1) in hydrogenation of cyclopentanone $3 \mathbf{a}$ with molecular hydrogen $(80$ bars) led to very low yields and $e e$ values of the secondary alcohol $7 \mathbf{a}$; the best $e e$ of $12 \%$ (31\% isolated yield) was obtained with Noyori's bifunctional ruthenium catalyst $\mathbf{C 4}$.

After report by Itsuno ${ }^{18}$ that chiral aminoalcohols together with $\mathrm{BH}_{3}$ effected the enantioselctive reduction of prochiral ketones, Corey ${ }^{19}$ isolated the primarily formed oxazaborolidine derivative, and developed a powerful catalytic version of an original stoichometric reduction. Con-

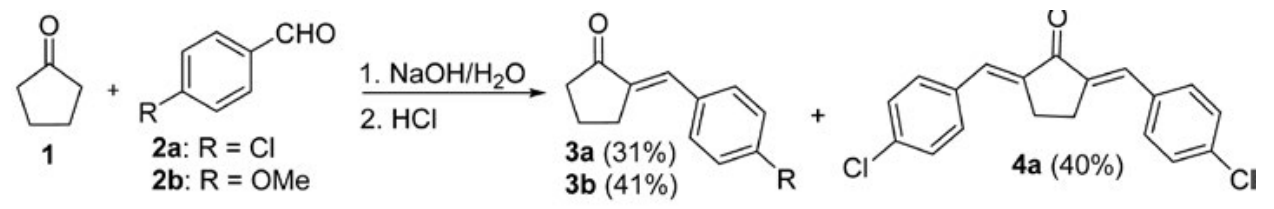<smiles>CO[C@H](O)c1ccc2c(c1)C(=O)/C(=C/c1ccc(Cl)cc1)C2</smiles>

Scheme 1. Synthesis of $\alpha$-arylmethylene cyclic ketones 3, 4 and 6 .<smiles></smiles>

C1

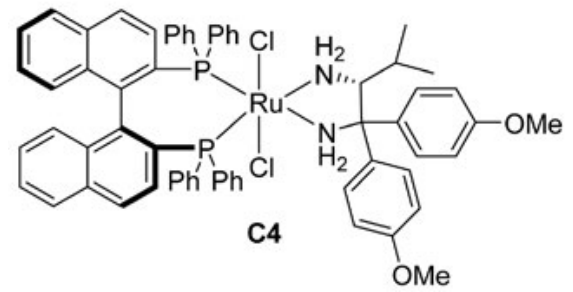

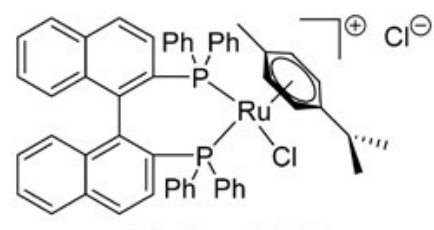

$(R)-\mathrm{C} 2$ or $(S)-\mathrm{C} 2$

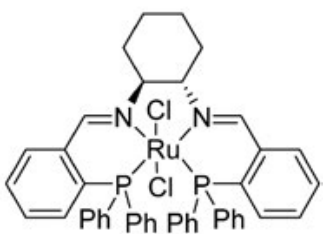

C3

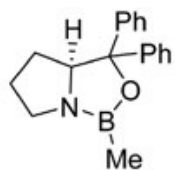

(S)-C5

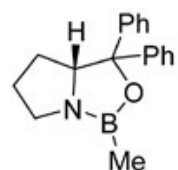

(R)-C5

Figure 1. Chiral catalysts employed in the asymmetric reduction of cyclic ketones $\mathbf{3}$ and $\mathbf{6}$. 
sequently, enantioselective reduction of prochiral ketones with borane (or its derivatives) catalyzed by chiral oxazaborolidines has emerged as an excellent route to alcohols of high enantiomerical purity. ${ }^{20}$ Since this method has many advantages such as predictable absolute configuration and high ee of chiral secondary alcohol products, it seemed logical to investigate whether oxazaborolidine-catalysed reduction of ketones $\mathbf{3}$ and $\mathbf{6}$ could afford the desired exocyclic allylic alcohols in high enantioselectivity. Indeed, the borane reduction of chlorobenzylidenecyclopentanone $3 \mathbf{a}$ in the presence of $10 \mathrm{~mol} \%$ of oxazaborolidine catalyst $(S)$-C5 at room temperature afforded the desired alcohol (R)-7a in 77\% ee (as juged by chiral HPLC) (Table 1, entry 1 ). By varying different solvents, reaction temperatures, amount of reductant, and catalyst loading (Table 1, entries 2-8), the highest $e e$ of $96 \%$ in reduction of 3a was achieved with 1.88 equiv. $\mathrm{BH}_{3} \times \mathrm{Me}_{2} \mathrm{~S}, 20 \mathrm{~mol} \%(S)$ $\mathrm{C} 5$ in toulene at $0{ }^{\circ} \mathrm{C}$. Typically, reduction was carried out by slow addition of a toluene solution of the ketone to an ice-cooled toluene solution of $\mathrm{BH}_{3} \times \mathrm{Me}_{2} \mathrm{~S}$ and catalyst (stirred for $10 \mathrm{~min}$ prior to adding the ketone). The same protocol was used in the reduction of the methoxy-substituted analogue $\mathbf{3 b}$ giving $(R)-\mathbf{7 b}$ but with significant loss of enantioselectivity (Table 1, entry 9 ). The opposite enantio- mers, $(S)-7 \mathbf{a}$ and $(S)-\mathbf{7} \mathbf{b}$, were obtained by the borane reduction with the oxazaborolidine catalyst $(R)$-C5 (Table 1 , entries 10 and 11). Interestingly, chloro-substituted alcohols $(S)-7 \mathbf{a}$ and $(R)-7 \mathbf{a}$ were obtained with practically identical ee values ( 95\%), while catalyst $(R)$-C5 reduced methoxy-benzylidenecyclopentanone $\mathbf{3 b}$ with increased enantioselectivity compared to catalyst $(S)$-C5 $(90 \%$ vs. $82 \% e e$ ). A dramatic drop in chemical yield and optical purity of the indanol alcohol 6 was observed in reduction of the indanone derivative $\mathbf{6}$ with either $(S)$-C5 or $(R)$-C5 catalyst. In spite of applying different reaction conditions (Table 1, entries 12-17), the corresponding alcohol 8 was not obtained in ee higher than 33\%. Lower ee values associated with asymmetric reduction of indanone $\mathbf{6}$ as compared to cyclopentanone 3 may suggest that a fused benzene ring has a pronounced influence on the level of asymmetric induction with oxazaborolidine catalysts C5. Additionally, low isolated yield of indanol 8 might be due to its decomposition (or of parent ketone) under applied reaction conditions as was also established for reduction of analogous indanone-derived chalcones. ${ }^{21}$

The enantiomeric excess of the allylic alcohols 7 and 8 was determined by chiral stationary phase HPLC. The corresponding racemic alcohols were synthesized by che-

Table 1: Asymmetric reduction of cyclic ketones $\mathbf{3 a}, \mathbf{b}$ and $\mathbf{6}$ with oxazaborolidine catalysts $\mathbf{C 5 .}$
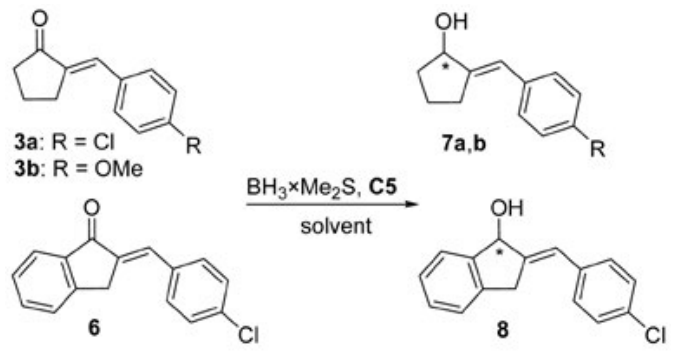

\begin{tabular}{|c|c|c|c|c|c|c|c|c|}
\hline entry & ketone & $\begin{array}{l}\text { catalyst } \\
\text { (mol\%) }\end{array}$ & solvent & $\begin{array}{c}\mathrm{BH}_{3} \times \mathrm{Me}_{2} \mathrm{~S} \\
(\text { equiv.) }\end{array}$ & $\mathrm{T}\left({ }^{\circ} \mathrm{C}\right)$ & product & $\operatorname{yield}^{\mathrm{a}}(\%)$ & $e e^{\mathrm{b}}(\%)$ \\
\hline 1 & $3 a$ & $(S)-\mathbf{C} 5,10$ & THF & 1.10 & r.t. & $7 a$ & n.d. & $77(R)$ \\
\hline 2 & $3 a$ & $(S)-\mathbf{C} 5,10$ & THF & 2.74 & -20 & $7 a$ & 88 & $81(R)$ \\
\hline 3 & $3 \mathbf{a}$ & $(S)-\mathbf{C} 5,10$ & THF & 1.70 & -20 & $7 \mathbf{a}$ & 67 & $32(R)$ \\
\hline 4 & $3 \mathbf{a}$ & $(S)-\mathbf{C 5}, 10$ & $\mathrm{THF}$ & 3.42 & -20 & $7 a$ & 91 & $75(R)$ \\
\hline 5 & $3 \mathbf{a}$ & $(S)-\mathbf{C 5}, 20$ & DCM & 1.70 & -6 & $7 a$ & 84 & $90(R)$ \\
\hline 6 & $3 \mathbf{a}$ & $(S)-\mathbf{C} 5,10$ & $\mathrm{THF}$ & 2.74 & 0 & $7 \mathbf{a}$ & 82 & $88(R)$ \\
\hline 7 & $3 a$ & $(S)-\mathbf{C} 5,10$ & THF & 1.70 & 0 & $7 a$ & 80 & $90(R)$ \\
\hline 8 & $3 a$ & $(S)-\mathbf{C} \mathbf{5}, 20$ & toluene & 1.88 & 0 & $7 a$ & 77 & $96(R)$ \\
\hline 9 & $3 b$ & $(S)-\mathbf{C} 5,20$ & toluene & 1.88 & 0 & $7 \mathbf{b}$ & 67 & $82(R)$ \\
\hline 10 & $3 \mathbf{a}$ & $(R)-\mathbf{C 5}, 20$ & toluene & 1.88 & 0 & $7 a$ & 70 & $95(S)$ \\
\hline 11 & $3 b$ & $(R)-\mathbf{C 5}, 20$ & toluene & 1.88 & 0 & $7 \mathbf{b}$ & 59 & $90(S)$ \\
\hline 12 & 6 & $(R)-\mathbf{C} 5,20$ & toluene & 1.88 & 0 & 8 & 15 & 23 \\
\hline $13^{\mathrm{c}, \mathrm{d}}$ & 6 & (R)-C5, 20 & toluene $/ \mathrm{CH}_{2} \mathrm{Cl}_{2}$ & 2.10 & 0 & 8 & 21 & 24 \\
\hline $14^{\mathrm{d}}$ & 6 & $(S)-\mathbf{C 5}, 20$ & toluene $/ \mathrm{CH}_{2}^{2} \mathrm{Cl}_{2}^{2}$ & 1.27 & 0 & 8 & 20 & 33 \\
\hline 15 & 6 & $(S)-\mathbf{C 5}, 20$ & $\mathrm{CH}_{2} \mathrm{Cl}_{2}$ & 1.27 & 0 & 8 & 19 & 21 \\
\hline $16^{\mathrm{e}, \mathrm{f}}$ & 6 & $(S)-\mathbf{C 5}, 20$ & $\mathrm{THF}^{2}$ & 1.27 & -30 & - & - & - \\
\hline $17^{\mathrm{e}}$ & 6 & $(S)-\mathbf{C 5}, 20$ & $\mathrm{CH}_{2} \mathrm{Cl}_{2}$ & 1.27 & -30 & 8 & 22 & 19 \\
\hline
\end{tabular}

${ }^{a}$ Isolated yield is given. ${ }^{b}$ Determined by chiral HPLC. ${ }^{c}$ First solution of $\mathbf{6}$ added to a solution of $(R)$ - $\mathbf{C 5}$, then $\mathrm{BH}_{3} \times \mathrm{Me}_{2} \mathrm{~S}$. ${ }^{\mathrm{d}} \mathrm{Ketone}$ dissolved in $\mathrm{CH}_{2} \mathrm{Cl}_{2}$, and catalyst in toluene. ${ }^{\mathrm{R}} \mathrm{Reaction}$ quenched with $\mathrm{MeOH}$. ${ }^{\mathrm{f}}$ The desired alcohol was not isolated. 

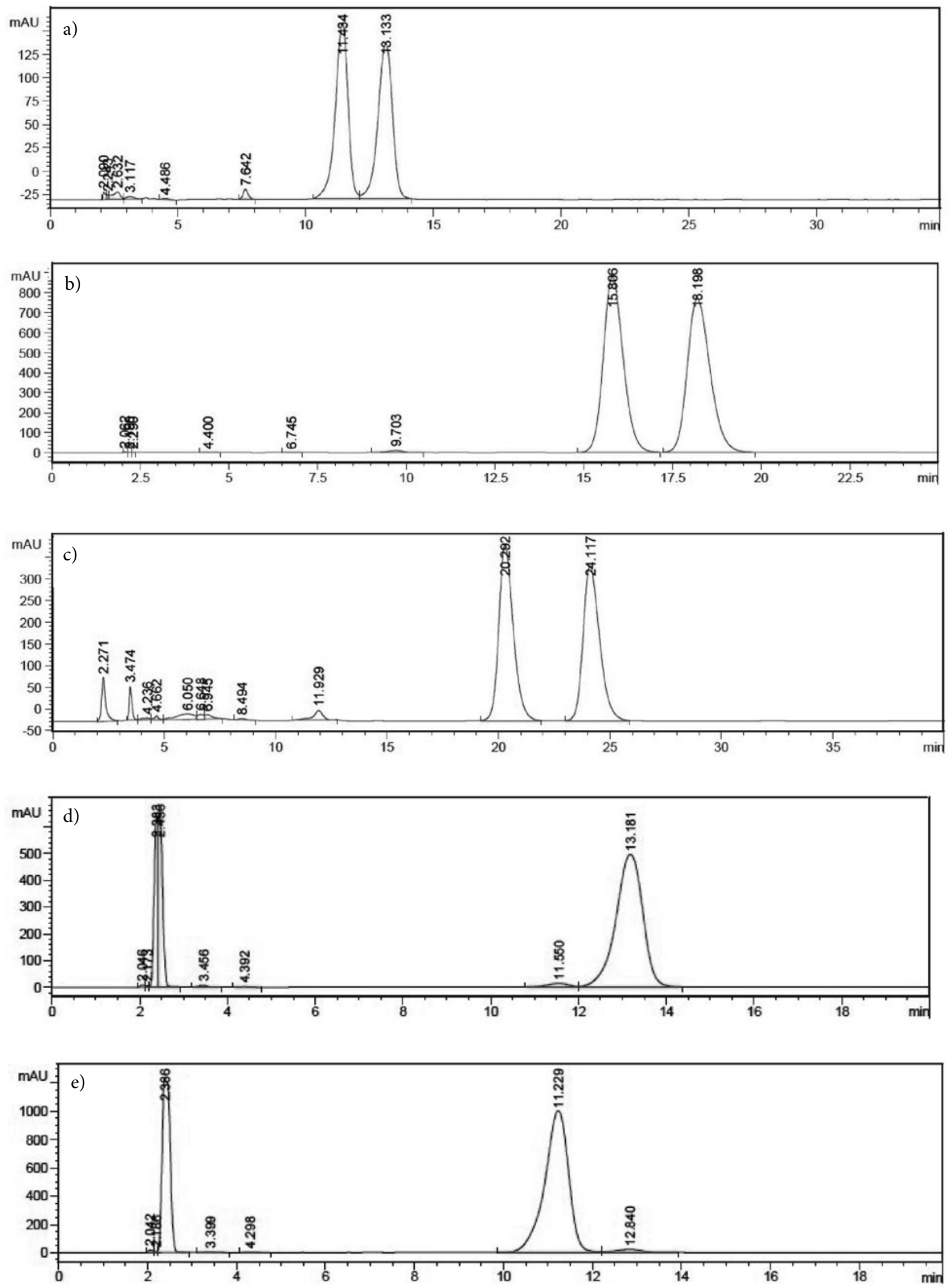

Štefane et al.: Asymmetric Bio- and Chemoreduction ... 

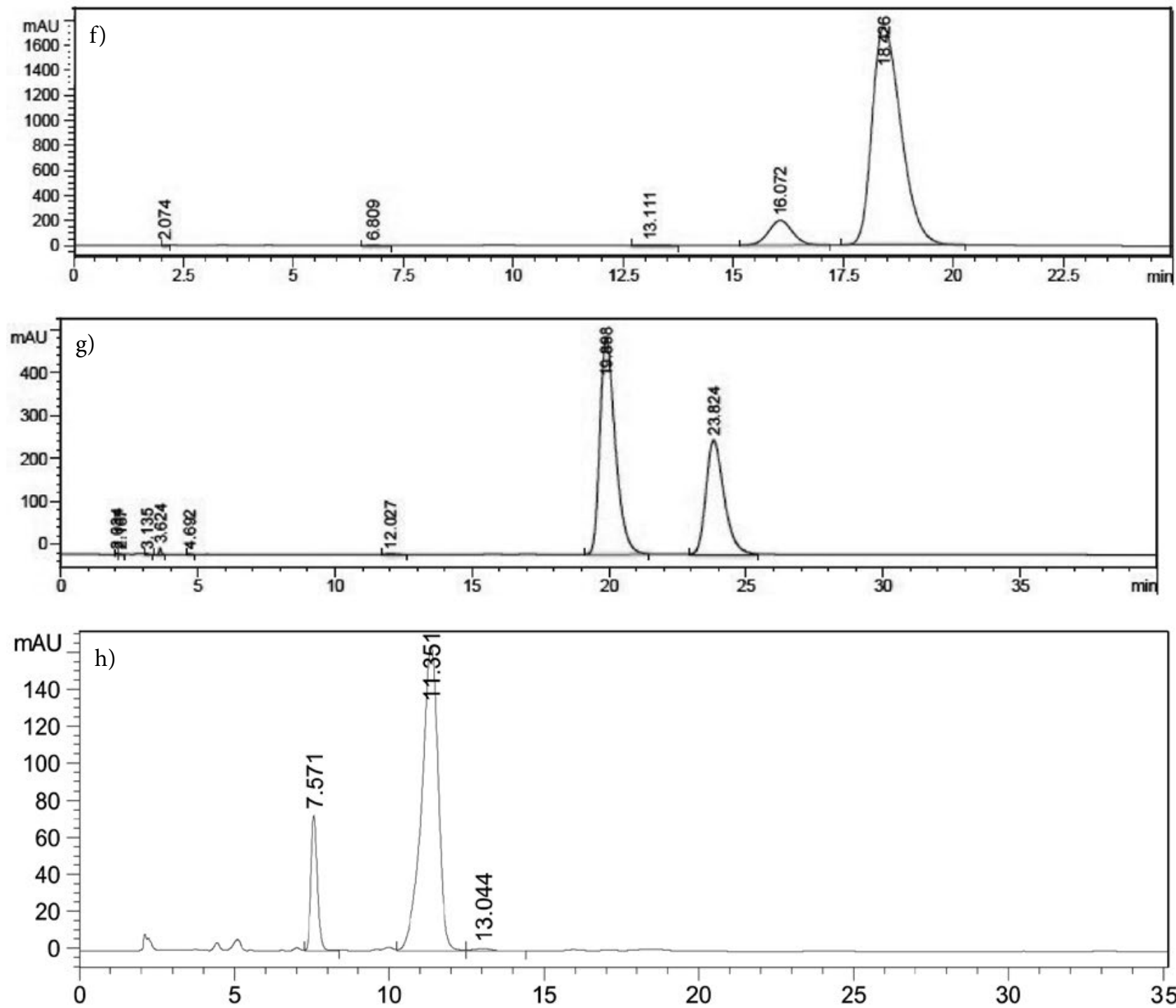

Figure 2. Chromatograms of (a) racemic alcohol 7a, (b) racemic alcohol 7b, (c) racemic alcohol 8, (d) enantiomerically enriched $(R)$-7a obtained with $(S)$-C5, (e) enantiomerically enriched $(S)$-7a obtained with $(R)$-C5, (f) enatiomerically enriched $(R)$-7b obtained with $(S)$-C5, (g) alcohol $\mathbf{8}$ obtained with $(R)-\mathbf{C 5}$, (h) enantiomerically enriched $(R)-7$ a obtained with Daucus carota root reduction.

moselective reduction with $\mathrm{NaBH}_{4}$ in the presence of $\mathrm{CeCl}_{3} \times 6 \mathrm{H}_{2} \mathrm{O}$. They were used to find the optimal HPLC conditions for the separation of the pairs of the enatiomeric alcohols.

Although Corey's (S)-proline-derived or stereochemically related oxazaborolidines in general delivered $R$-configured allylic alcohols in reduction of enones ${ }^{22}$ the $R$ absolute configuration of chlorobenzylidenecyclopentanol 7a obtained from reduction with $(S)$-C5 was unambigously confirmed by X-ray crystallography (Figure 3). Additionally, this established also the configuration around the exocyclic $\mathrm{C}=\mathrm{C}$ double bond as $E$. It should be made clear that stereochemical assignment for $(R)-7$ a has not been previously made, although the absolute stereochemistry of related 2-benzylidenecyclopentanol obtained with Corey $(S)$-oxazaborolidine catalyst was determined to be
$R .{ }^{23}$ Thus, formation of the alcohol $(R)-7 \mathbf{a}$ from chloro-substituted cyclopentanone $\mathbf{3 a}$ in the presence of oxazaborolidine catalyst (S)-C5 is also consistent with the sense of asymmetric induction predicted by the Corey mechanistic model. ${ }^{24}$ Consequently, we ascribed the $R$ stereochemistry also to the methoxy-substituted alcohol $7 \mathbf{b}$ provided by oxazaborolidine catalyst $(S)$-C5, while for alcohols $\mathbf{7 a}, \mathbf{b}$ arising from the borane reduction with catalyst $(R)-\mathbf{C} 5$ the $S$ configuration was concluded. This was further supported by comparison of the sense of optical rotation and HPLC elution sequence of the enantiomeric forms of the alcohols $7 \mathbf{a}$ and $\mathbf{7 b}$ obtained with catalysts $(S)-\mathbf{C 5}$ and $(R)$ C5, respectively. Examination of the chromatogram (d) depicted in Figure 2 reveals, that for chloro-cyclopentanol 7a delivered with catalyst $(S)$-C5, the $(+)-(R)$-form of the enantiomers separated on chiral column is eluted second. 
Methoxy-cyclopentanol 7b obtained with catalyst (S)-C5 (Figure 2, chromatogram (f)) is also eluted second and returned a specific rotation of $[\alpha]_{D}^{25}+3.8$, identical in sign to that of $(R)-7 \mathbf{a}$; consequently its configuration was proposed to be $R$. The opposite enantiomers of $7 \mathbf{a}$ and $7 \mathbf{b}$, ob-

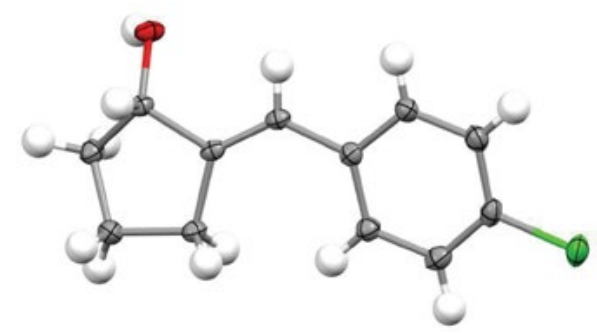

Figure 3. X-ray crystal structure of $(R)-7 \mathbf{a}$; thermal ellipsoids are set at $40 \%$ probability.

Table 2 Crystallographic data, structure refinement summary, selected bond lengths, bond angles, and torsion angles for compound (R)-7a.

\begin{tabular}{ll}
\hline Property & Compound $(\boldsymbol{R})-7 \mathbf{a}$ \\
\hline Empirical formula & $\mathrm{C}_{12} \mathrm{H}_{13} \mathrm{ClO}$ \\
Formula weight & 208.67 \\
Temperature & $150(2)$ \\
Crystal system & orthorhombic \\
Space group & $\mathrm{P} 22_{1} 2_{1}$ \\
$a(\AA)$ & $4.99305(10)$ \\
$b(\AA)$ & $9.3428(2)$ \\
$c(\AA)$ & $22.2446(4)$ \\
$\alpha\left({ }^{\circ}\right)$ & 90.00 \\
$b\left(^{\circ}\right)$ & 90.00 \\
$\gamma\left({ }^{\circ}\right)$ & 90.00 \\
Volume $\left(\AA^{3}\right)$ & $1037.69(4)$ \\
$Z$ & 4 \\
$F(000)$ & 440 \\
$\mathrm{Crystal}$ size $(\mathrm{mm} 3)$ & $0.08 \times 0.25 \times 0.60$ \\
$\mu(\mathrm{CuKla})(/ \mathrm{mm})$ & 0.079 \\
$N$ ref & 6371 \\
$\mathrm{R}$ & 0.0327 \\
$\mathrm{w}$ & 0.0876 \\
$\mathrm{~S}$ & 1.08 \\
\hline Bond length $(\AA)$ & \\
\hline $\mathrm{C} 2(1)-\mathrm{Cl}(1)$ & \\
$\mathrm{C}(8)-\mathrm{C}(9)$ & $10.0(1)$ \\
$\mathrm{O}(1)-\mathrm{C}(10)$ & $-4.5(1)$ \\
\hline Bond angles $\left({ }^{\circ}\right)$ & \\
\hline $\mathrm{C}(5)-\mathrm{C}(7)-\mathrm{C}(8)$ & $1.7440(16)$ \\
$\mathrm{C}(8)-\mathrm{C}(9)-\mathrm{C}(11)$ & $1.336(2)$ \\
$\mathrm{C}(8)-\mathrm{C}(9)-\mathrm{C}(10)$ & $1.4238(19)$ \\
$\mathrm{C}(9)-\mathrm{C}(10)-\mathrm{O}(1)$ & $129.9(2)$ \\
\hline Torsion angles $\left({ }^{\circ}\right)$ & $115.2(1)$ \\
\hline $\mathrm{C}(5)-\mathrm{C}(7)-\mathrm{C}(8)-\mathrm{C}(9)$ & \\
$\mathrm{C}(7)-\mathrm{C}(8)-\mathrm{C}(9)-\mathrm{C}(11)$ & \\
\hline & \\
\hline & \\
\hline & \\
\hline
\end{tabular}

tained with catalyst $(R)$-C5, both eluted on column first and the samples show levorotatory character. The dominant enantiomer of the indanol alcohol 8 obtained with $(R)$-C5, though in low excess, also eluted first on chiral column (Figure 2, chromatogram (g)), and the optical rotation of the sample was measured as $[\alpha]_{D}^{25}-13.4$. On this basis it can be speculated that catalyst $(R)-\mathbf{C 5}$ preferentially delivers the $(S)$-indanol $\mathbf{8}$ in the reduction of indanone 6, while with catalyst $(S)$-C5 the $(R)$-alcohol $\mathbf{8}$ is obtained as the major enantiomer.

Efficient asymmetric reduction of carbonyl compounds can also be achieved by means of bioreduction employing either isolated enzymes or whole cells system as mild and environmentally benign reduction systems. Fogliato et al. used baker's yeast ${ }^{25}$ for the reduction of arylidene cyclopentanones and cyclohexanones reaching satisfactory enantioselectivity, while the secondary alcohols of excellent optical purity were obtained from Daucus carota ${ }^{26}$ root reduction of structurally different prochiral ketones (up to $100 \%$ ee). Similarly, an $\alpha, \beta$-unsaturated ketone trans-4-phenylbut-3-en-2-one was regio- and stereoselectively reduced using carrot, celeriac, and beetroot enzyme systems to the corresponding ( $S$ )-allylic alcohol in ee's 72-99\%. ${ }^{27}$ In our case, the baker's yeast reduction of chlorobenzylidenecyclopentanone 3a gave very low isolated yield $(5 \%)$ and optical purity (ee $=9 \%)$ of the corresponding alcohol $7 \mathbf{a}$ even after incubating the reaction mixture at $38{ }^{\circ} \mathrm{C}$ for 10 days. On the contrary, the 24-hour-bioreduction with Daucus carota root (substrate/carrot, 1/134 $(\mathrm{w} / \mathrm{w})$ ) delivered alcohol $(S)-7 \mathbf{a}$ with $>99 \%$ ee as determined in the crude product (Figure 2, chromatogram (h)), the amount of which was, however, very low after removal of the biomaterial (Scheme 2). Interestingly, asymmetric induction turned out to be time-dependent, namely ee value of $(S)$-7a reduced to $92 \%$ after incubating reaction mixture for four days at room temperature. It is noteworthy that isolation of the desired alcohol product from bioreduction is intrinsically messy, as the aqueous media contains the cellular mass, usual metabolites, nutrients, and the starting ketone.

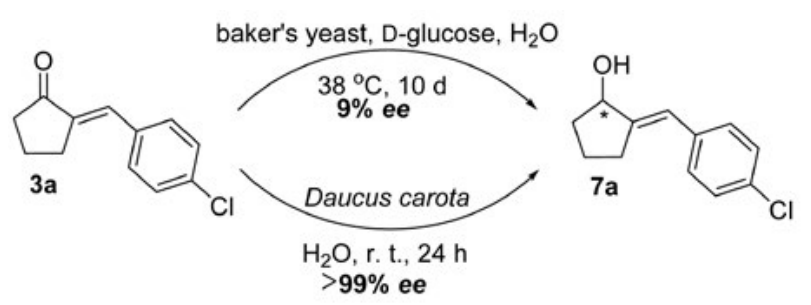

Scheme 2. Bioreduction of benzylidenecyclopentanone 3a.

\section{Experimental}

General. Toluene was dried with sodium and distilled. All other reagents and solvents were used as received from commercial suppliers. Melting points were deter- 
mined on a Kofler micro hot stage. The NMR spectra were recorded at $302 \mathrm{~K}$ either on a Bruker Avance DPX 300 or Avance III $500 \mathrm{MHz}$ spectrometer operating at $300 \mathrm{MHz}$ or $500 \mathrm{MHz}$ and $75.5 \mathrm{MHz}$ or $126 \mathrm{MHz}$ for ${ }^{1} \mathrm{H}$ and ${ }^{13} \mathrm{C}$ nuclei. The ${ }^{1} \mathrm{H}$ NMR spectra in $\mathrm{CDCl}_{3}$ are referenced with respect to TMS as the internal standard. The ${ }^{13} \mathrm{C}$ NMR spectra are referenced against the central line of the solvent signal $\left(\mathrm{CDCl}_{3}\right.$ triplet at $\left.\delta=77.0 \mathrm{ppm}\right)$. The coupling constants $(J)$ are given in $\mathrm{Hz}$. The multiplicities are indicated as follows: $\mathrm{s}$ (singlet), $\mathrm{d}$ (doublet), $\mathrm{t}$ (triplet), $\mathrm{q}$ (quartet), qn (quintet), $\mathrm{m}$ (multiplet) and br (broad). IR spectra were obtained on a Bruker FTIR Alpha Platinum ATR spectrophotometer. MS spectra were recorded with an Agilent 6224 Accurate Mass TOF LC/MS instrument. Elemental analyses $(\mathrm{C}, \mathrm{H}, \mathrm{N})$ were performed with a Perkin-Elmer 2400 Series II CHNS/O Analyzer. TLC was carried out on Fluka silica gel TLC-cards. Column chromatography was performed on 230-400-mesh silica gel. Merck silica gel 60 PF254 containing gypsum was used to prepare chromatotron plates. Radial chromatography was performed with Harrison Research, model 7924T chromatotron. HPLC analyses were performed with Agilent Technology 1260 Infinity HPLC instrument with UV detection. The known compounds were characterized by comparison of their physical or spectrosopic data with those in the literature.

Synthesis of ketones 3a and 4a: Cyclopentanone (1) (5.0 $\mathrm{g}, 59.4 \mathrm{mmol}$ ) and p-chlorobenzaldehyde (2a) (4.22 g, $30.02 \mathrm{mmol}$ ) were added into a $0.2 \mathrm{M}$ aqueous $\mathrm{NaOH}$ solution $(210 \mathrm{~mL})$, and stirred at room temperature for 72 $\mathrm{h}$. The reaction was quenched with water $(210 \mathrm{~mL})$, and the reaction mixture was acidified with $3.6 \%$ aqueous $\mathrm{HCl}$ solution $(60 \mathrm{~mL})$ to $\mathrm{pH} \sim 4$. The product was extracted with $\mathrm{CH}_{2} \mathrm{Cl}_{2}(3 \times 150 \mathrm{~mL})$, and combined organic layers were dried over anhydrous $\mathrm{Na}_{2} \mathrm{SO}_{4}$. The solvent was evaporated in vacuo, and the residue was purified by $\mathrm{SiO}_{2}$ column chromatography (petroleum ether : EtOAc $=20: 1$ ) to give $1.90 \mathrm{~g}(31 \%)$ of $\mathbf{3 a}$ and $4.00 \mathrm{~g}(40 \%)$ of $\mathbf{4 a}$.

2-(4-Chlorobenzylidene)cyclopentanone (3a): mp 74$76^{\circ} \mathrm{C}\left(\right.$ lit. $\left.{ }^{28} 77-79^{\circ} \mathrm{C}\right)$.

2,5-Bis(4-chlorobenzylidene)cyclopentanone (4a): $\mathrm{mp}$ 225-227 ${ }^{\circ} \mathrm{C}$ (lit. $\left.{ }^{29} 224-226^{\circ} \mathrm{C}\right)$.

Synthesis of 2-(4-methoxybenzylidene)cyclopentanone (3b): Cyclopentanone (1) $(1.0 \mathrm{~g}, 11.89 \mathrm{mmol})$ and $p$-methoxybenzaldehyde (2b) $(896 \mathrm{mg}, 6.58 \mathrm{mmol})$ were added into a $0.2 \mathrm{M}$ aqueous $\mathrm{NaOH}$ solution $(90 \mathrm{~mL})$, and stirred at room temperature for $24 \mathrm{~h}$, to which additional amount of cyclopentanone $(298 \mathrm{mg}, 3.54 \mathrm{mmol}$ ) was added, and stirred for further $12 \mathrm{~h}$. The reaction was quenched with water $(90 \mathrm{~mL})$, and the reaction mixture was acidified with $3.6 \%$ aqueous $\mathrm{HCl}$ solution $(20 \mathrm{~mL})$ to $p \mathrm{H} \sim 4$. The product was extracted with $\mathrm{CH}_{2} \mathrm{Cl}_{2}(3 \times 100 \mathrm{~mL})$, and the combined organic layers were dried over anhydrous $\mathrm{Na}_{2} \mathrm{SO}_{4}$.
The solvent was evaporated in vacuo, and the residue was purified by $\mathrm{SiO}_{2}$ column chromatography (petroleum ether : $\mathrm{EtOAc}=10: 1)$ to give $843 \mathrm{mg}(41 \%)$ of yellow crystalline product. $\mathrm{Mp} 65.4-66.3^{\circ} \mathrm{C}\left(\right.$ lit. $\left.^{28} 68-69^{\circ} \mathrm{C}\right)$.

Synthesis of 2-(4-chlorobenzylidene)-2,3-dihydro- $1 \mathrm{H}$ inden-1-one (6): To a solution of 1-indanone (5) (4.0 g, $30.27 \mathrm{mmol}$ ) and p-chlorobenzaldehyde (2a) $(5.32 \mathrm{~g}, 37.85$ $\mathrm{mmol})$ in $\mathrm{MeOH}(20 \mathrm{~mL})$, a $0.2 \mathrm{M}$ aqueous $\mathrm{NaOH}$ solution $(250 \mathrm{~mL})$ was added and the reaction mixture was stirred at room temperature for $48 \mathrm{~h}$. The reaction was quenched with water $(200 \mathrm{~mL})$, and the reaction mixture was acidified with $3.6 \%$ aqueous $\mathrm{HCl}$ solution $(60 \mathrm{~mL})$ to $p \mathrm{H} \sim 1$. The product was extracted with $\mathrm{CH}_{2} \mathrm{Cl}_{2}(3 \times 150$ $\mathrm{mL}$ ) and combined organic layers were dried over anhydrous $\mathrm{Na}_{2} \mathrm{SO}_{4}$. The solvent was evaporated in vacuo and the residue was purified by $\mathrm{SiO}_{2}$ column chromatography (petroleum ether : EtOAc $=50: 1 ; 20: 1 ; 10: 1 ; 5: 1 ; 2: 1$ ) to give $732 \mathrm{mg}$ (9\%) of light yellow crystalline product. Mp $180.4-181.0^{\circ} \mathrm{C}\left(\right.$ lit. $\left.^{30} 179^{\circ} \mathrm{C}\right)$.

Typical procedure for the synthesis of racemic alcohols - ( \pm )-2-(4-chlorobenzylidene)cyclopentanol ( \pm )-(7a): 2-(4-Chlorobenzylidene)cyclopentanone (3a) (400 mg, $1.94 \mathrm{mmol}$ ) and $\mathrm{CeCl}_{3} \times 6 \mathrm{H}_{2} \mathrm{O}$ were dissolved in $\mathrm{MeOH}$ $(20 \mathrm{~mL})$, and stirred at room temperature for $30 \mathrm{~min}$. Then solid $\mathrm{NaBH}_{4}(296 \mathrm{mg}, 7.83 \mathrm{mmol}$ ) was added portion-wise. After 15 min additional amount of $\mathrm{NaBH}_{4}(140 \mathrm{mg}, 3.70$ $\mathrm{mmol}$ ) was added, and stirred for further $1 \mathrm{~h}$. The reaction was quenched with $1 \mathrm{M}$ aqueous $\mathrm{HCl}$ solution $(10 \mathrm{~mL})$ and water $(40 \mathrm{~mL})$. The reaction mixture was stirred for $30 \mathrm{~min}$ and then extracted with EtOAc $(3 \times 50 \mathrm{~mL})$. The combined organic layers were successively washed with $5 \%$ aqueous $\mathrm{NaHCO}_{3}$ solution $(50 \mathrm{~mL})$, water $(30 \mathrm{~mL})$, and brine $(30$ $\mathrm{mL}$ ), and dried over anhydrous $\mathrm{Na}_{2} \mathrm{SO}_{4}$. The solvent was evaporated in a vacuo to give $360 \mathrm{mg}(89 \%)$ of white crystalline product $( \pm)-(7 \mathbf{a}), \mathrm{mp} 76-77^{\circ} \mathrm{C}$. IR (ATR) v 3358, 2964, 1911, 1705, 1620, 1493, 1405, 1325, 1243, 1166, 1143, 1090, 1027, 1009, 980, 940, 887, 823, $730 \mathrm{~cm}^{-1} .{ }^{1} \mathrm{H}$ NMR $\left(500 \mathrm{MHz}, \mathrm{CDCl}_{3}\right) \delta 1.60$ (br s, $\left.1 \mathrm{H}, \mathrm{OH}\right), 1.61-1.68$ and 1.70-1.79 $\left(2 \times \mathrm{m}, 2 \times 1 \mathrm{H}, \mathrm{CH}_{2}\right), 1.93-2.02\left(\mathrm{~m}, 2 \mathrm{H}, \mathrm{CH}_{2}\right)$, 2.51-2.59 and 2.65-2.74 $\left(2 \times \mathrm{m}, 2 \times 1 \mathrm{H}, \mathrm{CH}_{2}\right), 4.59(\mathrm{~m}, 1 \mathrm{H}$, $\mathrm{OCH}$ ), 6.53 (br q, $J 2.5 \mathrm{~Hz}, 1 \mathrm{H}, \mathrm{C}=\mathrm{CH}$ ), $7.28\left(\mathrm{AA}^{\prime} \mathrm{BB}^{\prime}, J 8.8\right.$ $\mathrm{Hz}, 2 \mathrm{H}, \mathrm{Ar}$ ), 7.30 (AA'BB', $J 8.8 \mathrm{~Hz}, 2 \mathrm{H}, \mathrm{Ar}) .{ }^{13} \mathrm{C}$ NMR $(125$ $\left.\mathrm{MHz}, \mathrm{CDCl}_{3}\right) \delta 22.3,29.2,34.7,77.1,122.4,128.4,129.5$, 132.1, 136.2, 148.3. ESI-HRMS $(\mathrm{m} / \mathrm{z}):\left[\mathrm{M}+\mathrm{H}-\mathrm{H}_{2} \mathrm{O}\right]^{+}$calcd for $\mathrm{C}_{12} \mathrm{H}_{12} \mathrm{Cl}$, 191.0622; found, 191.0627 .

( \pm )-2-(4-Methoxybenzylidene)cyclopentanol $\quad( \pm)-(7 b)$ : Prepared by the above procedure from $\mathbf{3 b}$ (100 mg, 0.49 mmol). Yield $71 \%$, mp $75.5-78.3{ }^{\circ} \mathrm{C}$. IR (ATR) v 3252, 2998, 2955, 2931, 2833, 1604, 1510, 1463, 1420, 1294, 1242, $1178,1112,1034,973,938,886,831,753 \mathrm{~cm}^{-1} .{ }^{1} \mathrm{H}$ NMR $\left(500 \mathrm{MHz}, \mathrm{CDCl}_{3}\right) \delta 1.50(\mathrm{~s}, 1 \mathrm{H}, \mathrm{OH}), 1.62-1.69$ and $1.72-$ $1.79\left(2 \times \mathrm{m}, 2 \times 1 \mathrm{H}, \mathrm{CH}_{2}\right), 1.89-2.01\left(\mathrm{~m}, 2 \mathrm{H}, \mathrm{CH}_{2}\right), 2.50-$ 2.59 and $2.67-2.75\left(2 \times \mathrm{m}, 2 \times 1 \mathrm{H}, \mathrm{CH}_{2}\right), 3.82(\mathrm{~s}, 3 \mathrm{H}, \mathrm{Me})$,

Štefane et al.: Asymmetric Bio- and Chemoreduction ... 
$4.58(\mathrm{~m}, 1 \mathrm{H}, \mathrm{OCH}), 6.52(\mathrm{br} \mathrm{q}, J 2.5 \mathrm{~Hz}, 1 \mathrm{H}, \mathrm{C}=\mathrm{CH}), 6.88$ (AA'BB', J $8.8 \mathrm{~Hz}, 2 \mathrm{H}, \mathrm{Ar}$ ), 7.30 (AA'BB', J $8.8 \mathrm{~Hz}, 2 \mathrm{H}, \mathrm{Ar}$ ). ${ }^{13} \mathrm{C}$ NMR $\left(125 \mathrm{MHz}, \mathrm{CDCl}_{3}\right) \delta 22.7,29.3,34.9,55.2,77.5$, 113.7, 123.2, 129.6, 130.5, 145.5, 158.2. ESI-HRMS $(\mathrm{m} / z)$ : $\left[\mathrm{M}+\mathrm{H}-\mathrm{H}_{2} \mathrm{O}\right]^{+}$calcd for $\mathrm{C}_{13} \mathrm{H}_{15} \mathrm{O}, 187.1117$; found, 187.1114. Analytical data are in agreement with the literature data. ${ }^{17}$

( \pm )-2-(4-Chlorobenzylidene)-2,3-dihydro- $1 H$-inden-1-ol ( \pm )-(8): Prepared by the above procedure from 6 (125 mg, $0.49 \mathrm{mmol}$ ). Yield 39\%, mp $105.8-108.6{ }^{\circ} \mathrm{C}$. IR (ATR) v 3319, 3069, 3025, 2887, 2321, 2155, 2107, 1904, $1692,1677,1608,1586,1490,1461,1405,1354,1312,1296$, $1255,1212,1186,1176,1133,1092,1009,954,895,866$, $844,823,806,745,732 \mathrm{~cm}^{-1} .{ }^{1} \mathrm{H}$ NMR $\left(500 \mathrm{MHz}, \mathrm{CDCl}_{3}\right)$ $\delta 1.97$ (br s, $1 \mathrm{H}, \mathrm{OH}), 3.79-3.99\left(\mathrm{~m}, 2 \mathrm{H}, \mathrm{CH}_{2}\right), 5.62$ (br s, $1 \mathrm{H}, \mathrm{OCH}), 6.86(\mathrm{br} \mathrm{q}, J 2.5 \mathrm{~Hz}, 1 \mathrm{H}, \mathrm{C}=\mathrm{CH}), 7.27-7.32(\mathrm{~m}$, $3 \mathrm{H}, \mathrm{Ar}), 7.34-7.37$ (m, 4H, Ar), 7.51-7.55 (m, 1H, Ar). ${ }^{13} \mathrm{C}$ NMR $\left(125 \mathrm{MHz}, \mathrm{CDCl}_{3}\right) \delta 35.5,78.3,124.8,124.9$, $125.1,127.3,128.6,128.8,129.8,132.7,135.5,140.7,142.9$, 145.5. ESI-HRMS $(\mathrm{m} / z):\left[\mathrm{M}+\mathrm{H}-\mathrm{H}_{2} \mathrm{O}\right]^{+}$calcd for $\mathrm{C}_{16} \mathrm{H}_{12} \mathrm{Cl}$, 239.0622; found, 239.0612 .

Typical procedure for the asymmetric reduction with oxazaborolidines - synthesis of $(R)$-2-(4-chlorobenzylidene)cyclopentanol $(\boldsymbol{R})-(7 \mathbf{a})$. To the ice-cooled $\left(0{ }^{\circ} \mathrm{C}\right)$ solution of $(S)$-C5 $(0.1 \mathrm{~mL}, 0.1 \mathrm{mmol} ; 1 \mathrm{M}$ in toluene) in dry toluene ( $1 \mathrm{~mL}), \mathrm{BH}_{3}: \mathrm{Me}_{2} \mathrm{~S}(470 \mu \mathrm{L}, 0.94 \mathrm{mmol} ; 2 \mathrm{M}$ in toluene) was added dropwise, and the mixture was strirred for $10 \mathrm{~min}$. A solution of ketone $\mathbf{3 a}(0.5 \mathrm{mmol})$ in dry toluene $(1 \mathrm{~mL})$ was slowly added to the previously prepared solution of reductant at $0{ }^{\circ} \mathrm{C}$. After completion (jugded by TLC) of the reaction, the mixture was evaporated, and the residue purified by $\mathrm{SiO}_{2}$ radial chromatography (petroleum ether : EtOAc $=5: 1)$ to give $80 \mathrm{mg}(77 \%)$ of enantiomerically enriched product. $96 \% e e ; t_{\mathrm{R}}=11.6 \mathrm{~min}$ (minor), $13.2 \mathrm{~min}$ (major), (chiracel OD-H chiral column, mobile phase: $i$ - $\mathrm{PrOH} /$ hexane $=98 / 2$, flow rate: $1.5 \mathrm{~mL} / \mathrm{min}$, wavelength: $240 \mathrm{~nm}),[\alpha]_{\mathrm{D}}^{25}+41.3\left(1.13, \mathrm{CH}_{2} \mathrm{Cl}_{2}\right)$.

(S)-2-(4-Chlorobenzylidene)cyclopentanol (S)-(7a): for the synthesis details see Table 1, entry 10 . Yield 70\%, 95\% $e e ; t_{\mathrm{R}}=11.2 \mathrm{~min}$ (major), $12.8 \mathrm{~min}$ (minor) (chiracel OD-H chiral column, mobile phase: $i-\mathrm{PrOH} /$ hexane $=$ 98/2, flow rate: $1.5 \mathrm{~mL} / \mathrm{min}$, wavelength: $240 \mathrm{~nm}),[\alpha]_{\mathrm{D}}^{25}-$ $31.9\left(1.17, \mathrm{CH}_{2} \mathrm{Cl}_{2}\right)$.

(R)-2-(4-Methoxybenzylidene)cyclopentanol (R)-(7b): for the synthesis details see Table 1, entry 9. Yield $67 \%$, $82 \% e e ; t_{\mathrm{R}}=16.1 \mathrm{~min}$ (minor), $18.4 \mathrm{~min}$ (major), (chiracel OD-H chiral column, mobile phase: $i-\mathrm{PrOH} /$ hexane $=$ 98/2, flow rate: $1.5 \mathrm{~mL} / \mathrm{min}$, wavelength: $240 \mathrm{~nm}$ ), $[\alpha]_{\mathrm{D}}^{25}+$ $3.8\left(1.11, \mathrm{CH}_{2} \mathrm{Cl}_{2}\right)$.

(S)-2-(4-Methoxybenzylidene)cyclopentanol (S)-(7b): for the synthesis details see Table 1, entry 11 . Yield 59\%,
$90 \% e e ; t_{\mathrm{R}}=16.0 \mathrm{~min}$ (major), $18.7 \mathrm{~min}$ (minor) (chiralcel OD-H), $i$ PrOH:heksan $=98: 2,1.5 \mathrm{ml} / \mathrm{min},[\alpha]_{\mathrm{D}}^{25}-9.9$ $\left(1.08, \mathrm{CH}_{2} \mathrm{Cl}_{2}\right)$.

2-(4-Chlorobenzylidene)-2,3-dihydro- $1 H$ - inden-1-ol (8): for the synthesis details see Table 1, entry 13. Yield $21 \%, 24 \%$ ee; $t_{\mathrm{R}}=19.9 \min$ (major), $t_{\mathrm{R}}=23.8 \mathrm{~min}$ (minor) (chiracel OD-H chiral column, mobile phase: $i-\mathrm{PrOH} /$ hexane $=98 / 2$, flow rate: $1.5 \mathrm{~mL} / \mathrm{min}$, wavelength: 240 $\mathrm{nm}),[\alpha]_{\mathrm{D}}^{25}-13.4\left(0.96, \mathrm{CH}_{2} \mathrm{Cl}_{2}\right)$.

2-(4-Chlorobenzylidene)-2,3-dihydro- $1 H$-inden-1-ol (6): for the synthesis details see Table 1, entry 14 . Yield $20 \%, 33 \% e e ; t_{\mathrm{R}}=20.3 \min$ (minor), $t_{\mathrm{R}}=24.1 \mathrm{~min}$ (major) (chiracel OD-H chiral column, mobile phase: $i-\mathrm{PrOH} /$ hexane $=98 / 2$, flow rate: $1.5 \mathrm{~mL} / \mathrm{min}$, wavelength: 240 $\mathrm{nm})$.

Hydrogenation of 3a with Noyori's catalyst C4: 2-(4Chlorobenzylidene)cyclopentanone (3a) (103 mg, 0.498 $\mathrm{mmol})$, catalyst C4 $(6 \mathrm{mg}, 4.9 \mu \mathrm{mol})$ and isopropanol (2 $\mathrm{mL}$ ) were added to hydrogenation vessel under nitrogen atmosphere. Then $\mathrm{K}_{2} \mathrm{CO}_{3}(10 \mathrm{mg}, 0.072 \mathrm{mmol})$ was added, the autoclave was pressurized to 80 bars of $\mathrm{H}_{2}$, and the reaction mixture was stirred at room temperature. After 2 days additional amount of $\mathbf{C 4}(4.6 \mathrm{mg}, 3.8 \mu \mathrm{mol})$ was added (ketone $\mathbf{3 a}$ still present). Because the ketone $\mathbf{3 a}$ was still not consumed after 7 days, additional amount of $\mathrm{K}_{2} \mathrm{CO}_{3}$ (50 mg, $0.362 \mathrm{mmol}$ ) was added. After additional 5 days the reaction was still not complete, therefore $\mathrm{K}_{2} \mathrm{CO}_{3}(10$ $\mathrm{mg}, 0.072 \mathrm{mmol}$ ), catalyst $\mathbf{C 4}(5 \mathrm{mg}, 4.1 \mu \mathrm{mol})$ and isopropanol $(1 \mathrm{~mL})$ were added, and hydrogenated for further 4 days. The solvent was evaporated and the residue was purified by $\mathrm{SiO}_{2}$ column chromatography (petroleum ether : $\mathrm{EtOAc}=5: 1)$ to afford $32 \mathrm{mg}(31 \%)$ of the product $7 \mathbf{a} ; \mathrm{ee}$ $=12 \%$.

Reduction of 3a with baker's yeast: To a stirred solution of D-glucose $(10.0 \mathrm{~g}, 55.5 \mathrm{mmol})$ and baker's yeast $(56.0 \mathrm{~g})$ in water $(200 \mathrm{~mL})$ at $38^{\circ} \mathrm{C}, 2$-(4-chlorobenzylidene)cyclopentanone (3a) $(1.0 \mathrm{~g}, 4.84 \mathrm{mmol})$ dissolved in the minimum amount of EtOH $(5 \mathrm{~mL})$ was added; the reaction mixture was stirred for 10 days. Then EtOAc $(100 \mathrm{~mL})$ was added and the crude reaction mixture was filtered through a pad of Celite. The filtrate was extracted with EtOAc $(3 \times$ $100 \mathrm{~mL}$ ), the organic phase was dried over anhydrous Na${ }_{2} \mathrm{SO}_{4}$, and the solvent was evaporated under reduced pressure. The residue was purified by $\mathrm{SiO}_{2}$ column chromatography (petroleum ether : EtOAc $=5: 1$ ) to afford $45 \mathrm{mg}$ $(5 \%)$ of the product $7 \mathbf{a}$ as a light yellow oil; $e e=9 \%$.

Reduction of 3a with Daucus carota root: An ethanolic $(5 \mathrm{~mL})$ solution of 2-(4-chlorobenzylidene)cyclopentanone (3a) $(100 \mathrm{mg}, 0.484 \mathrm{mmol})$ was added to a suspension of freshly grated carrot root $(13.4 \mathrm{~g})$ in water $(70 \mathrm{~mL})$. The raction mixture was stirred at room temperature for 
$24 \mathrm{~h}$, then carrot root was filtered off and washed with water. Filtrate was extracted with EtOAc $(3 \times 50 \mathrm{~mL})$. The organic phase was dried over anhydrous $\mathrm{Na}_{2} \mathrm{SO}_{4}$ and the solvent was evaporated under reduced pressure to give 10 mg (10\%) of crude red oily product $7 \mathbf{a} ; e e>99 \%$.

\section{Conclusion}

In summary, we synthesized enantiomerically enriched exocyclic allylic alcohols by asymmetric reduction of cyclic $a$-arylmethylene cyclic ketones. Highly enantioselective chemoreduction of 2-benzylidenecyclopentanone derivatives was achieved by applying chiral oxazaborolidine-derived catalysts under mild reaction conditions. The sense of asymmetric induction was in accordance with Corey mechanistic model, thus $(S)$-catalyst delivered $(R)$-alcohols, while $(R)$-catalyst gave $(S)$-alcohol products with $e e$ values of up to $96 \%$. The indanone-derived chalcone was much less efficiently reduced regarding the chemical yield and optical purity $(33 \% e e)$. Bioreduction of 2-(4-chlorobenzylidene)cyclopentanone with baker's yeast gave very low ee of the corresponding allylic alcohol, while reduction with Daucus carota root turned out to be completely enantioselective. The synthesized allylic alcohols can serve as enantioenriched probes for the monitoring of oxidation-reduction processes catalyzed by AKR1C enzymes; these studies are currently under progress.

\section{Acknowledgments}

We acknowledge with thanks the financial support from the Slovenian Research Agency through grant P10179. We thank EN-FIST Centre of Excellence, Trg Osvobodilne fronte 13, 1000 Ljubljana, Slovenia, for using SuperNova diffractometer and FTIR spectrophotometer. We also thank D. Potočnik for laboratory assistance.

\section{References}

1. H.-U. Blaser, C. Malan, B. Pugin, F. Spindler, H. Steiner, M. Studer, Adv. Synth. Catal. 2003, 345, 103-151. (a) T. M. Penning, Chem. Biol. Interact. 2015, 234, 236-246; (b) Y. Jin, T. M. Penning, Annu. Rev. Pharmacol. Toxicol. 2007, 47, 263-292;

(c) U. Oppermann, Annu. Rev. Pharmacol. Toxicol. 2007, 47, 293-322.

3. (a) P. Brožič, S. Turk, T. L. Rižner, S. Gobec, Curr. Med. Chem. 2011, 18, 2554-2565; DOI:10.2174/092986711795933713

(b) T. L. Rižner, T. M. Penning, Steroids 2014, 79, 49-63. DOI:10.1016/j.steroids.2013.10.012

4. (a) T. M. Penning, M. E. Burczynski, J. M. Jez, C.-F. Hung, H.K. Lin, H. Ma, M. Moore, N. Palackal, K. Ratnam, Biochem. J. 2000, 351, 67-77; (b) S. Steckelbroeck, Y. Jin, S. Gopishet- ty, B. Oyesanmi, T. M. Penning, J. Biol. Chem. 2004, 279, 10784-10795; DOI:10.1074/jbc.M313308200

(c)O.A.Barski,S.M.Tipparaju,A.Bhatnagar,Drug.Metab.Rev., 2008, 40, 553-624. DOI:10.1080/03602530802431439

5. (a) T. M. Penning, J. E. Drury, Arch. Biochem. Biophys. 2007, 464, 241-250; DOI:10.1016/j.abb.2007.04.024

(b) T. M. Penning, M. C. Byrns, Ann. N. Y. Acad. Sci. 2009, 1155, 33-42; DOI:10.1111/j.1749-6632.2009.03700.x

(c) B. E. Henderson, H. S. Feigelson, Carcinogenesis 2000, 21, 427-433; DOI:10.1093/carcin/21.3.427

(d) P. Brožič, S. Turk, T. L. Rižner, S. Gobec, Curr. Med. Chem. 2011, 18, 2554-2565. DOI:10.2174/092986711795933713

6. A. Krazeisen, R. Breitling, G. Möller, J. Adamski, Mol. Cell. Endocrinol. 2001, 171, 151-162.

DOI:10.1016/S0303-7207(00)00422-6

7. N. Usami, T. Yamamoto, S. Shintani, Y. Higaki, S. Ishikura, Y. Katagiri, A. Hara, Biol. Pharm. Bull. 2002, 25, 441-445.

DOI:10.1248/bpb.25.441

8. P. Brožič, B. Golob, N. Gomboc, T. L. Rižner, S. Gobec, Mol. Cell. Endocrinol. 2006, 248, 233-235.

DOI:10.1016/j.mce.2005.10.020

9. Y. Higaki, N. Usami, S. Shintani, S. Ishikura, O. El-Kabbani, A. Hara, Chem. Biol. Interact. 2003, 143, 503-513.

DOI:10.1016/S0009-2797(02)00206-5

10. K. Traven, M. Sinreih, J. Stojan, S. Seršen, J. Kljun, J. Bezenšek, B. Stanovnik, I. Turel, T. L. Rižner, Chem. Biol. Interact. 2015, 234, 349-359. DOI:10.1016/j.cbi.2014.11.005

11. P. Brožič, S. Turk, A. O. Adeniji, J. Konc, D. Janežič, T. M. Penning, T. L. Rižner, S. Gobec, J. Med. Chem. 2012, 55, 74177424. DOI:10.1021/jm300841n

12. S. Gobec, P. Brožič, T. L. Rižner, Bioorg. Med. Chem. Lett. 2005, 15, 5170-5175. DOI:10.1016/j.bmcl.2005.08.063

13. B. Štefane, P. Brožič, M. Vehovc, T. L. Rižner, S. Gobec, Eur. J. Med. Chem. 2009, 44, 2563-2571.

DOI:10.1016/j.ejmech.2009.01.028

14. N. Beranič, B. Štefane, B. Brus, S. Gobec, T. L. Rižner, Chem. Biol. Interact. 2013, 202, 204-209.

DOI:10.1016/j.cbi.2012.12.003

15. A. P. Phillips, J. Mentha, J. Am. Chem. Soc. 1956, 78, 140-145. DOI: $10.1021 / \mathrm{ja} 01582 \mathrm{a} 040$

16. (a) B. Štefane, F. Požgan, Top. Curr. Chem. 2016, 374, 1-67; DOI:10.1007/s41061-015-0002-2

(b) B. Štefane, F. Požgan, Cat. Rev. Sci. Eng. 2014, 56, 82-174; DOI:10.1080/01614940.2013.869461

(c) F. Požgan, B. Štefane in: I. Karamé (Ed.): Hydrogenation: Asymmetric hydrogenation and transfer hydrogenation of ketones, InTech, Rijeka, Croatia, 2012, pp. 31-68.

17. J.-B. Xie, J.-H. Xie, X.-Y. Liu, W.-L. Kong, S. Li, Q.-L. Zhou, J. Am. Chem. Soc. 2010, 132, 4538-4539.

DOI:10.1021/ja100652f

18. A. Hirao, S. Itsuno, N. Nakahama, N. Yamazaki, J. Chem. Soc., Chem. Commun 1981, 315-317.

DOI: $10.1039 / \mathrm{c} 39810000315$

19. E. J. Corey, R. K. Bakshi, S. Shibata, J. Am. Chem. Soc. 1987, 109, 5551-5553. DOI:10.1021/ja00252a056

20. E. J. Corey, C. J. Helal, Angew. Chem. Int. Ed. 1998, 37, 
1986-2012. DOI:10.1002/(SICI)1521-3773(19980817)37:15 <1986::AID-ANIE1986>3.0.CO;2-Z

21. T. Yildız, Tetrahedron: Asymmetry 2015, 26, 497-504. DOI:10.1016/j.tetasy.2015.03.008

22. (a) E. J. Corey, R. K. Bakshi, S. Shibata, C.-P. Chen, V. K. Singh, J. Am. Chem Soc. 1987, 109, 7925-7926. DOI:10.1021/ja00259a075

(b) E. J. Corey, A. V. Gavai, Tetrahedron Lett. 1988, 29, 3201-3204; DOI:10.1016/0040-4039(88)85121-9

(c) E. J. Corey, J. O. Link, Tetrahedron Lett. 1989, 30, 62756278; DOI:10.1016/S0040-4039(01)93871-7

(d) E. J. Corey, R. K. Bakshi, Tetrahedron Lett. 1990, 31, 611-614; C. Y. Hong, N. Kado, L. E. Overman, J. Am. Chem. Soc. 1993, 115, 11028-11029.

23. A. F. Simpson, C. D. Bodkin, C. P. Butts, M. A. Armitage, T. Gallagher, J. Chem. Soc., Perkin Trans 1 2000, 3047-3054. DOI: 10.1039/b004540n

24. (a) D. A. Evans, Science 1988, 240, 420-426;
DOI:10.1126/science.3358127

(b) D. K. Jones, D. C. Liotta, J. Org. Chem. 1993, 58, 799-801; DOI:10.1021/jo00056a001

(c) L. P. Linney, C. R. Self, I. H. Williams, J. Chem. Soc., Chem. Commun. 1994, 1651-1652. DOI:10.1039/C39940001651

25. G. Fogliato, G. Fronza, C. Fuganti, S. Lanati, R. Rallo, R. Rigoni, S. Servi, Tetrahedron 1995, 51, 10231-10240. DOI:10.1016/0040-4020(95)00578-V

26. J. S. Yadav, S. Nanda, P. T. Reddy, A. B. Rao, J. Org. Chem. 2002, 67, 3900-3903. DOI:10.1021/jo010399p

27. E. Majewska, M. Kozłowska, Tetrahedron Lett. 2013, 54, 6331-6332. DOI:10.1016/j.tetlet.2013.09.041

28. M Austin, O. J. Egan, R. Tully, A. C. Pratt, Org. Biomol. Chem. 2007, 5, 3778-3786. DOI:10.1039/b711620a

29. J.-X. Wang, L. Kang, Y. Hu, B. guo Wei, Synth. Commun. 2002, 32, 1691-1696. DOI:10.1081/SCC-120004261

30. N. P. Buu-Hoï, N. D. Xuong, J. Chem. Soc. 1952, 2225-2228. DOI:10.1039/JR9520002225

\section{Povzetek}

Učinkovita asimetrična redukcija 2-benzilidenciklopentanonskih derivatov s kiralnimi oksazaborolidinskimi katalizatorji vodi selektivno do nastanka eksocikličnih alilnih alkoholov z enantiomernimi presežki do $96 \%$. Popolno enantioselektivnost lahko dosežemo z bioredukcijo 2-(4-klorobenziliden)ciklopentanona s korenjem, pri čemer nastane ustrezen alkohol z $S$ konfiguracijo. Sintetizirane spojine lahko služijo kot enantiomerno obogateni standardi pri spremljanju encimsko kataliziranih 